\title{
Entrepreneurial Motivation and Venture Performance: an Intensive Review
}

\author{
Rita Subedi, M.Phil. \\ Lecturer, Tribhuvan University \\ Email: ritasubedismc@gmail.com
}

\begin{abstract}
Human motivation has been treated as a significant determinant of initiating work related behavior and subsequently getting optimal performance. The relationship of motivation, behavior and performance is commonly tested in several domains of human life (e.g. education, health, sports, exercise, work etc.). However, application of motivation approach in the domain of entrepreneurship is only in its infancy. Hence, this paper aims to review literature intensively that makes a clear direction for the study related to entrepreneurial motivation and suggests new research line for the future. The results found two major directions in the study of entrepreneurial motivation. The first includes the studies treating motivation as a unitary variable with partial and linking role in comprehensive framework. The second includes the studies treating motivation as multifacted construct with central role. The study helps to broaden the knowledge in the field of entrepreneurial motivation and its role to be entrepreneur.
\end{abstract}

Keywords: entrepreneurial motivation, venture Performance, entrepreneurial process, psychological dimension, self-regulated behavior

\section{Introduction}

Entrepreneurial motivation refers the energy or willingness of an individual to recognize an opportunity and deploy resources to exploit it (Fini et al., 2014). It is defined as a combination of internal psychological mechanism of an entrepreneur and his/her individual context and environmental factors that channel energy, direction, determination, persistence and intention to identify novel idea, its implementation management, pursue goals and maintain entrepreneurial spirit where others see chaos and confusion (Kuratko, 2014).

Entrepreneurial motivation represents a psychological dimension of entrepreneurship. It is also called one of the most important dimension of personal approach of entrepreneurship. Large numbers of previous research have stated the importance of personal approach in the entrepreneurship domain. They include mostly an entrepreneur's personality traits (Åstebro, Herz, Nanda, \& Weber, 2014; Rauch \& Frese, 2007a, 2007b; Rauch, 2014; Rahafar, Castellana, Randler, \& Antunez, 2017), individual 
dispositions (Fellows, 2016), and entrepreneurial motivation (Stephan, Hart, \& Drews, 2015; Fellows, 2016; Fairlie \& Fossen, 2019).

Among them, the study of entrepreneurial motivation is newly emerging. Despite this, the study of entrepreneurial motivation has provided many insights, such as some startup studies focus on a single motivation (Wu et al., 2007) or identify a list of motivations through factor analysis (Carter et al., 2003), examining motivation types and their antecedents in isolation (Stephan, Hart, \& Drews, 2015), role of multiple motivations for action or self-regulated behavior (Deci \& Ryan, 1985; Segal et al., 2005; Deci \& Rayan, 2000), entrepreneurial intention (Kim-Soon et al., 2018), action/ behavior, and outcomes they produced in entrepreneurial process and influence of individual and contextual driver to motivation and performance outcomes (Kuratko, 2014).

Researchers using motivation approach for entrepreneurship have common belief that the biological, cognitive and social regulations of an entrepreneur are the core of motivation. As a result, entrepreneurial motivation predicts a self-regulated behavior that subsequently leads optimal performance to generate better results (Deci \& Rayan, 2000, $2004, \&$ 2017). Hence, it is claimed that motivation plays a significant role in all stages of entrepreneurial process (e.g. entrepreneurial mind set, opportunity identification and evaluation, searching resources and designing the mechanism to exploit opportunity) in general, and venture performance in particular (Berthelot, 2008; Baptista, Karaöz, \& Mendonça, 2014; Fellows, 2016; Fairlie \& Fossen, 2019). However, most of the studies have only theoretically explained the role of entrepreneurial motivation in different stage of entrepreneurial process in general and venture performance in particular. Hence, there is an obvious lacuna of an empirical analysis.

In this context, this paper aims to review literature related to entrepreneurial motivation that have been studied in the hope of making a clear understanding about its role in entrepreneurship and to identify new lines of research in this area. The article will adopt the following scheme: i) gradual development related to role of entrepreneurial motivation, and consequence it produced, ii) discussion and conclusion. Finally, this paper suggests new research line for the future.

\section{Role of Entrepreneurial Motivation: Gradual Development and Consequences it Produced}

Entrepreneurship is multidimensional in nature. Previous researches have stated that organizational, personal and environmental dimensions are important in the study of entrepreneurship (Kuratko, 2014). Among them, entrepreneurial motivation is an emerging area associated with personal approach of entrepreneurship. Knowledge 
creation about the role of entrepreneurial motivation and consequences thereof in entrepreneurial process and performance have led to its gradual development from the studies treating motivation as a unitary construct to studies treating motivation as multifaceted construct. The studies treating entrepreneurial motivation as a unitary concept are based on the following two beliefs. They are;

i) Motivation plays a partial role within a comprehensive framework and

ii) Motivation plays a crucial link between a) Entrepreneurial intension and action/behavior; b) Satisfaction of human needs and performance.

Studies focused on first belief stated that motivation is a part of a comprehensive framework in the study of entrepreneurship. This includes several variables, such as availability of resources, personal context and environmental factors, organizational factors, motivation, education, ability and experience, entrepreneurial personality trait, individual disposition, intention, behavior, etc. Entrepreneurial performance is a combined effort of all variables associated in a comprehensive framework. Motivational one could not influence entrepreneurial process then performance. Evidence does not support this logic and claimed that entrepreneurial motivation is a critical component of entrepreneurship models. Moreover, motivation measured by venture internalization has a positive effect on performance satisfaction (Berthelot, 2008).

Studies focused on second belief stated that motivation plays linking role in between a) entrepreneurial intention and action/ behavior than outcomes and b) satisfaction of human needs and performance. Entrepreneurial activity (e.g. the establishment of new firms and the creation of new values in existing ones) is an outcome of an intentionally planned behavior. Without motivation, the entrepreneurial intention (e.g. an individual's conscious decision/conviction that someday, in the foreseeable future, they will become a self-employed entrepreneur) may fail to convert itself into action. Motivation serves as link between intention and action. Entrepreneurial activity is an intentionally planned behavior. Motivation stimulus could transform a latent intention to drive entrepreneurship (Edelman et al., 2010). Azen's Theory of Planned Behavior (TPB), a widely accepted theory, provides foundation to explain the intention action relationship. Evidence showed that entrepreneurial intention has the ability to predict both individual behaviors (Ajzen, 1991), and organizational outcomes such as survival, development and growth (Mitchel, 1981; Kim-Soon et al., 2018).

In addition to that, the linking role of motivation is found in between satisfaction of human needs and performance outcomes. Evidence showed the positive association of intrinsic motivation and satisfaction of basic psychological needs (e.g. need for 
autonomy, relatedness and competence) and wellbeing than performance (Ryan \& Deci, 2000).

When motivation has been a central and perennial issue in the field of psychology, it has gained importance in the field of entrepreneurship and the multifaceted concept of motivation has been developed. This concept is based on the assumption that all aspects of activation and intention of individual is due to motivation. Hence, biological, cognitive and social regulations of an entrepreneur are the core of motivation (Deci \& Rayan, 2000). Hence, it is claimed that motivation plays a central role in entrepreneurial process in general, and entrepreneurial performance in particular (Berthelot, 2008; Fellows, 2016; Kim-Soon et al., 2018; Fairlie \& Fossen, 2019). The studies treating motivation as multifaceted construct are based on following two beliefs;

i) the types or quality of entrepreneurial motivation plays an important role in all stage of entrepreneurial process, particularly performance outcome

ii) individual and contextual driver can foretell or thwart to entrepreneurial motivation and performance

The studies based on the first belief have identified several types of entrepreneurial motivation from the study of different entrepreneur, their individual context and external environment in different stages of entrepreneurial process. The major types are listed below;

1) Opportunity versus necessity motivation (Pull vs. Push motivation)

2) Multi-dimensional typologies of entrepreneurial motivation

3) Motivations to grow a business, or growth ambitions

4) Extrinsic and intrinsic motivation

5) Autonomous and controlled motivation

\section{Opportunity versus Necessity Motivation (Pull vs. Push Motivation)}

The opportunity versus necessity motivation is also called pull and push theory of motivation. Previous studies have stated that opportunity and necessity motivation have drawn a substantial amount of attention in recent years. The commonly used opportunity-necessity dichotomy has the longest standing conceptualization to measure entrepreneurial motivation (Fairlie \& Fossen, 2019).

The first category, opportunity motivation, is also called "Opportunity Entrepreneurship" (OE). Here, an opportunity refers to market opportunities and expectations of material gain (Segal et al., 2005). It means that opportunity entrepreneurs are individuals who start their business when they spot an opportunity in the market due to their expertise and 
skills for profit. A large number of pull factors (e.g. individual interest of independence, achievement, recognition, personal development, and personal wealth) have been identified that lead an individual towards opportunity entrepreneurship (Mkubukeli \& Cronje, 2018). Opportunity entrepreneurship is found to be positively associated with local economic conditions (Fairlie \& Fossen, 2019) and with more growth-oriented businesses (Baptista, Karaöz, \& Mendonça, 2014).

The second category, necessity motivation which is also called "Necessity Entrepreneurship” (NE). 'Necessity' refers to a lack of employment opportunities (Rouse, 2004). It means necessity entrepreneurs start their businesses when they cannot find another means of living or employment in the market. A large number of push factors (e.g. unemployment, job insecurity, disagreement with management, does not "fit in" with the organization no other alternatives) have been identified that lead an individual towards necessity entrepreneurship (Mkubukeli \& Cronje, 2018). NE is also categorized into soft necessity (it is due to internal factors like job dissatisfaction) and "hard" necessity (it is due to external factors like unemployment) (Mandják et al., 2011).

Necessity entrepreneurship is found negatively associated with local economic conditions (Fairlie \& Fossen, 2019), and poor association with growth-oriented businesses (Baptista, Karaöz, \& Mendonça, 2014).

However, necessity entrepreneurs make up an important part of the total set of entrepreneurs in developing countries, and are relatively less common in developed countries. For example, rates of necessity entrepreneurship for Brazil, Argentina, India and Chile ranged between 6.5 per cent and 7.5 per cent in 2002, compared to 0.33 per cent and 0.43 per cent in Denmark and Finland, respectively (Cowling \& Bygrave, 2002).

\section{Multi-dimensional Typologies of Entrepreneurial Motivation}

The multi-dimensional typology integrates other dimensions in addition to opportunity and necessity motivation. Different researchers have discussed different dimensions from the study of different individuals in various contexts. Stephan, Hart, and Drews (2015) have listed the seven most commonly identified dimensions in their study and claimed that these seven dimensions capture entrepreneurial motivation in sufficient breadth and depth. They are;

i) Achievement, challenge \& learning

ii) Independence \& autonomy

iii) Income security \& financial success

iv) Recognition \& status 
v) Family \& roles

vi) Dissatisfaction, and

vii) Community \& social motivation;

The first dimension, achievement, challenge \& learning, captures a desire for personal development through entrepreneurship. It includes aspects such as having meaningful work and responsibility and to learn through the challenge of creating/running a business. It also includes aspects of self-realization including fulfilling one's personal vision (Uddin \& Bose, 2013). Achievement motivation has found a positive upward linear relationship to entrepreneurial persistence with fairly strong correlation (Sabiu et al., 2018).

The dimension of 'independence \& autonomy' highlights entrepreneurial motivation to be able to control one's work life including control over one's own time and work, making independent decisions, having flexibility to combine work with one's personal life (Uddin \& Bose, 2013). Independence and autonomy is found as an expression of survival values in Russia and of self-expression values in the Netherlands (Gelderen et al., 2017).

The dimension 'income security \& financial success'captures the importance of financial returns from entrepreneurship (Edelman et al., 2010).

The dimension 'recognition \& status'captures the aspects related to social status such as the desire to receive recognition and respect from friends, family and the wider community for one's work as an entrepreneur. (Benzing \& Chu, 2009; Akehurst et al., 2012).

The 'family \& roles' dimension captures the desire to continue a family tradition as well as following the example of other role models (which are usefully not further specified in the studies themselves). In some studies, this dimension also emphasizes creating a family legacy (Benzing \& Chu, 2009; Edelman et al., 2010; Uddin \& Bose, 2013).

The 'dissatisfaction' dimension describes entrepreneurial motivation out of dissatisfaction with prior work arrangement (Akehurst et al., 2012). It, therefore, bears some similarity to necessity motivation, which is rarely explicitly included in this type of motivational.

The 'community \& social motivations' dimension includes the desire to contribute back to the community the entrepreneur lives in, either through philanthropy or the business itself (i.e. social entrepreneurship) (Estrin et al., 2013). 
Among seven dimensions associated in this multidimensional typology, dimensions like achievement, challenge \& learning; independence \& autonomy; income security \& financial success and recognition \& status are identified commonly in the study of investigating entrepreneurial motivation and used vigorously. On the other hand, the remaining three; i.e. family $\&$ roles, dissatisfaction and community \& social motivation are rarely identified, (Stephan, Hart, \& Drews, 2015).

In addition to that, previous studies have stated some other important motivational concepts in the study of entrepreneurship. This includes the need for achievement (nAch), risk taking propensity, tolerance for ambiguity, locus of control, self-efficacy, and goal setting.

The concept of needs of achievement (nAch) has received much attention under the domain of personality traits. It refers a desire/commitment to either meet or exceed performance standards. Entrepreneurial roles are characterized as having a greater degree of these task attributes (i.e. high degree of individual responsibility for outcomes, required individual skills and effort, have moderate degree of risk and include clear feedback on performance) than other careers. Thus it is likely that people in nAch will be more likely to pursue entrepreneurial jobs than other types of role. It is an effective tool for differentiating between founders and the general population (Collins, Locke, \& Hanges, 2000).

Risk taking propensity is another motivation of interest because entrepreneurs act in the face of uncertainty in an entrepreneurial process. It is concerned with how an individual prefers to take a risk and how he/she manages the risk in uncertain business situations. Individuals who have higher achievement motivation should prefer activities of intermediate risk because this type of activities will create challenge. However, firm owners do not differ significantly from managers or even the general population in risk taking.

The tolerance for ambiguity is related to propensity to view situations without clear outcomes as attractive rather than threatening. Because entrepreneurs continuously face more uncertainty in their environment than managers of established organizations. However, there is contradiction in findings. Miller and Drodge (1986) found firm founders were significantly higher in tolerance for ambiguity than were managers. Babb and Babb (1992) found no significant difference in tolerance for ambiguity between founders and non-founders.

Locus of control is another motivational trait that has received attention for the study of entrepreneurial motivation. It is related to a person's beliefs about the extent to which 
outcomes result from forces within (internal) and outside (external) of the person. An individual with an internal locus of control would be likely to seek entrepreneurial roles because they desire positions in which their actions have direct impact on results.

Self-efficacy is the belief in one's ability to muster and implement the necessary personal resources, skills and competencies to attain a certain level of achievement on a given task. Self-efficacy had a strong positive relationship with realized growth in the study of Baum (1994).

Goal-setting is a theory of motivation outlined by Locke and Latham in 1990. The theory believed that people's goal representations are the efficient causes of behavior and that people's performance will be maximized when (i) they set specific, difficult goals that have high valence and (ii) they understand what behaviors will lead to the goals and feel competent to do those behaviors.

\section{Motivations to Grow a Business, or Growth Ambitions}

Motivation to growth ambition typology is largely separate from these seven dimensions stated above. This dimension is concerned with the association of entrepreneurial motivation with growth ambitions. It means one's motivation to grow a business typically measured as a forecast about the future size of the business in terms of number of employees and sales (Stephan, Hart, \& Drews, 2015). A recent meta-analytic review summarizes the literature on entrepreneurial growth ambitions and suggests that forecasts of the future business size should be differentiated from intentions (motivation), that is, where the entrepreneurs states a preference for growth and growth plans (Levie \& Autio, 2013).

\section{Extrinsic and Intrinsic Motivation}

The forth typology used to investigating entrepreneurial motivation is extrinsic and intrinsic motivation. The extrinsic typology incorporates the decision of an individual to start a new business merely to get some money or to avoid unemployment or pressure from family, friends, mentors etc. An extrinsically motivated individual can produce positive outcome, when she/he integrates the value of entrepreneurship. Fellows (2016) found that extrinsic motivation have a positive significant relationship with the entrepreneurial performance, i.e. strong with firm net profit, moderate with personal income and weak with career satisfaction.

The intrinsic typology comprises of the decision of an individual to be involved in an entrepreneurial activity due to his/her interest to seek novelty and challenges, to extend and exercise one's capacities, to explore and to learn. Intrinsically motivated people are 
more likely to find the activity inherently interesting and enjoyable, engage in required tasks proactively, improve their skills, and experience greater levels of performance (Ryan \& Deci, 2000a). In the highest form, intrinsic motivation is called passion and can lead to complete absorption in the work (Csikszentmihalyi, 1990). It is expected that the performance of intrinsically motivated entrepreneur would be related to financial return based outcomes and career satisfaction. Evidence did not support it (Fellows, 2016). However, intrinsic motivation is important to cognitive and social development of individual that represents a principle source of enjoyment and vitality throughout life (Csikszentmihalyi \& Rathundle, 1993; Rayan, 1995) and the external monetary rewards of entrepreneurship are not nearly as powerful as the internal non-monetary rewards (Alstete, 2008). Thus, the collaborative effect of both intrinsic and extrinsic motivation will be supportive to measure entrepreneurial performance (Fellows, 2016).

\section{Autonomous and Controlled Motivation}

The fifth typology applied to investigate entrepreneurial motivation is autonomous and controlled motivation. These motivational reasons are either intrinsic or extrinsic. It means both types of motivation are relevant in entrepreneurship as people would not always start their ventures only because of intrinsic reason but also because of extrinsic reason as well.

Here, autonomous motivation comprises both intrinsic motivation and the types of extrinsic motivation (e.g. intrinsic and integrated) in which people have identified with an activity's value and ideally will have integrated it into their sense of self (internalization). When people are autonomously motivated, they experience more interest, excitement, confidence and volition, or a self-endorsement of their actions that manifests in enhanced performance and persistence (Ryan \& Deci, 2000, 2008). This mixture of intrinsic motivation and internalized external motivation is superior in situations that include both complex tasks that are interesting and in less complex tasks that require discipline (Koestener \& Losier, 2002).

Controlled motivation, in contrast, consists of both external motivation and introjected motivation. External motivation acts solely to obtain reward or to avoid punishment. Introjected motivation is internally controlled form of motivation in which the person acts to avoid feelings guilty or anxious. The difference between external and introjected motivation is that with external motivation the person feels controlled by external forces, whereas with introjected motivation, the person feels controlled by inner forces. When people are controlled, they experience pressure to think, feel, or behave in particular ways (Deci \& Ryan, 2008). 
These two types of motivation (autonomous and controlled) energize and direct behavior, and they stand in contrast to a motivation (lack of motivation or unwillingness). However, autonomous motivation and controlled motivation lead to very different outcomes. Autonomous motivation tends to yield greater psychological health and more effective performance on heuristic types of activities. It also leads to greater long-term persistence (Deci \& Ryan, 2008). Evidence showed that autonomouscontrolled motivation continuum predicts entrepreneurial performance (firm profit, individual profit, career satisfaction) more strongly than individual dispositions (risk, innovativeness, proactivity) in entrepreneurship (Fellows, 2016).

The study based on the second belief, individual and contextual driver, can foretell or thwart entrepreneurial motivation than performance have found a widely accepted way to investigate entrepreneurial motivation. The individual drivers are socio-demographic profile of an entrepreneur (e.g. gender, education, age, racial and ethnic background), personality differences and their ability to access resources. The contextual drivers represent the regional and national characteristics including formal institutions (e.g. property rights and welfare systems), informal institutions/national culture, and other macro-economic variables (National Wealth, Economic Growth and Resources) (Shepherd et al., 2015). Evidence support the logic that children will more easily internalize entrepreneurial goals and become autonomously regulated/ motivated if they perceive that parents experienced a state of mental wellbeing as entrepreneurs, and that they encourage such aspirations in their children (Iremadze, 2016).

Entrepreneurial motivation, either opportunity necessity or other type as stated above, are found to be a motivational base to start new business. Moreover, individual and contextual drivers support or thwart it. It has been implicitly assuming that start-up motivations influence all subsequent behavior rather than changing over the business life course with entrepreneur experience (Hessels et al., 2008; Kurtoko et al., 1997), Such as business performance (Levie \& Autio, 2013; Fellows, 2016), additional investments that entrepreneur make in their businesses (Dunkelberg et al., 2013), their satisfaction with their business (Berthelot, 2008).

\section{Discussion and Conclusion}

Personal approach is gaining importance in the study of entrepreneurship domain. The trait approach, behavioral approach and the motivation approach are more popular in this field. This paper intended to make an overall understanding of motivation approach in the field of entrepreneurship domain (i.e. entrepreneurial motivation) and the consequence it produced. After the intensive review of literature related to entrepreneurial motivation, It is found that several study have highlighted a significant 
role of entrepreneurial motivation in different stage of entrepreneurial process. The gradual development of the study have found treating motivation as singular to multifaceted construct. It means that the role of motivation is accounted nominal when it is treating as singular construct. The linking role of entrepreneurial motivation added its role in-between entrepreneurial intention and action and satisfaction of basic psychological needs and wellbeing and performance. Moreover, the types or quality of entrepreneurial motivation and individual and contextual drivers have explored the role of entrepreneurial motivation on venture performance, growth, and job creation. Thus, entrepreneurial motivation is gaining importance in the study of entrepreneurship domain.

However, most of study have been conducted in the context of developed country, and reason behind to start new business have taken motivation base to be entrepreneurial. Other motivational traits such as high need for achievement, locus of control, selfefficacy and risk taking propensity have used to differentiate an entrepreneur from a nonentrepreneurial population.

One important area which rarely covered in the study of entrepreneurial motivation is formation of self-regulated behavior for optimal performance. More specifically how entrepreneurial motivation is developed and shape self-regulated behavior of individual which subsequently produces optimal performance is found unanswered. This will provide an avenue for future research.

\section{References}

Ajzen, I. (1991). The theory of planned behavior. Organizational Behavior and Human Decision Processes, 50: 179-211.

Akehurst, G. Simarro, E. \& Mas-Tur, A. (2012). Women entrepreneurship in small service firms: motivations, barriers and performance. The Service Industries Journal, 32(15), 1-17.

Alstete, J. W. (2008). Aspects of entrepreneurial success. Journal of Small Business and Enterprise Development, 15(3), 584-594.

Åstebro, T., Herz, H., Nanda, R., \& Weber, R. A. (2014). Seeking the roots of entrepreneurship: Insights from behavioral economics. Journal of Economic Perspectives, 28(3), 49-70.

Babb, E. M., \& Babb, S. V. (1992). Psychological traits of rural entrepreneurs. Journal of Socio-Economics, 21, 353-362.

Baptista, R., Karaz, M., Mendonça, J. (2014), The Impact of Human Capital on the Early Success of Necessity versus Opportunity---based Entrepreneurs", Small Business Economics, 42(4), 831-847. 
Baum, R. (1994). The Relation of Traits, Competencies, Vision, Motivation, and Strategy to Venture Growth. Unpublished doctoral dissertation, University of Maryland, College Park, MD.

Benzing, C., \& Chu, H. M. (2009). A comparison of the motivations of small business owners in Africa. Journal of Small Business and Enterprise Development, 16(1), 60-77.

Berthelot, A. (2008). The Impact of Entrepreneurial Motivation on Venture Performance. Unpublished Thesis for the Degree of Doctor of Philosophy, The University of Texas at El Paso.

Carter, N. M., Gartner, W. B., Shaver, K. G., \& Gatewood, E. J. (2003). The career reasons of nascent entrepreneurs. Journal of Business Venturing, 18(1), 13-39.

Collins, C., Locke, E., \& Hanges, P. (2000). The relationship of need for achievement to entrepreneurial behavior: a meta-analysis. Working paper, University of Maryland, College Park, MD.

Cowling, M., \& Bygrave, W. (2002). Entrepreneurship and Unemployment: Relationships between Unemployment and Entrepreneurship in 37 Nations Participating in the Global Entrepreneurship Monitor'. GEM Consortium Working Paper.

Csikszentmihalyi, M. (1990). Flow: The psychology of optimal experience. New York: Harper Perennial.

Csikszentmihalyi, M., \& Rathundle, K. (1993).The measurement of flow in everyday life: Toward a theory of emergent motivation. In J.E.Jakobs(Ed). Development perspectives on motivation (pp.57-97) Lincoln: University of Nebraska Press.

Deci, E. L., \& Ryan, R. M. (2000). The "what" and "why" of goal pursuits: Human needs and the self-determination of behavior. Psychological Inquiry, 11, 227-268.

Deci, E. L., \& Ryan, R. M. (2008). Self-Determination Theory: A Macro theory of Human Motivation, Development, and Health, Canadian Psychology, 49(3), 182185.

Edelman L. F., Brush C. G., Manolova T. S., \& Greene P., G. (2010). Start-up motivations and growth intentions of minority nascent entrepreneurs. Journal of Small Business Management. 48(2), 174-196.

Estrin, S., Korosteleva, J. \& Mickiewicz, T. (2013). Which institutions encourage entrepreneurial growth aspirations? Journal of Business Venturing, 28(4), 564580.

Fairlie, R. W., \& Fossen, Frank M. (2019). Defining Opportunity versus Necessity Entrepreneurship: Two Components of Business Creation, NBER Working Paper 26377, 1050 Massachusetts Avenue Cambridge, MA 02138. 
Fellows, G. (2016). First principle at work; Self Determination Theory and the Mechanism of Organismic Integration over Individual Dispositions in Entrepreneurship. Unpublished thesis submitted in fulfilment of the requirement of degree of Master of Business. School of Management, QUT Business School.

Fini, R., Grimaldi, R., Marzocchi, G. L., Sobrero, M. (2014). The foundation of Entrepreneurial Intention. Department of Management of the University of Bologna, http://ssrn.com/abstract=1313225

Gelderen, M., Shirokova, G., Shchegolev, V., \& Beliaeva, T. (2017). Entrepreneurial Autonomy in Russia: A Comparison with the Netherlands.

Iremadze, D. (2016). Towards Entrepreneurial Motivation: The Self-Determination Theory Approach. 11th European Conference on Innovation and Entrepreneurship (ECIE) 2016, Jyväskylä, Finland.

Kim-Soon, N., Ahmad, A. R., \& Ibrahim, N. N. (2018). Understanding the Motivation that Shapes Entrepreneurship Career Intention. INTECH Open Science, open minds.

Kuratko, D. F. (2014). Entrepreneurship: Theory, Process and Practice. South-western 5191 Natorp Boulevard, Mason, OH 45040, USA.

Levie, J., \& Autio, E. (2013). Growth and growth intentions. Enterprise Research Centre, White paper 1.

Locke, E. A., \& Latham, G. P. (1990). A theory of goal setting and task performance. Englewood Cliffs, NJ: Prentice-Hall.

Mandják T., Bárdos C., Neuman-Bódi E., Németh S., Simon J. (2011). To solve the impossible: From necessity to success with the help of business network, IMP Journal, 5(3), 212-223.

Miller, D., \& Drodge, C. (1986). Psychological and traditional determinants of structure. Administrative Science Quarterly, 31, 539-560.

Mkubukeli, Z., \& Cronje J. (2018). Pull and Push Elements of Entrepreneurship in South Africa: A Small-Scale Mining Perspective. Journal of Entrepreneurship \& Organization Management, 7(3).

Rahafar, A., Castellana, I., Randler, C., Antunez, J. M. (2017). Conscientiousness but not Agreeableness Mediates Females’ Tendency Toward Being a Morning Person, Scandinavian Journal of Psychology, 58(3), 249-253.

Rauch, A. (2014). Predictions of entrepreneurial behavior: A personality approach. In E. Chell\& M. Karatas-Ozkan (Eds.) Handbook of Research on Small Business and Entrepreneurship. Edward Elgar, London, UK, 165-183.

Rauch, A., \& Frese, M. (2007a). Let's put the person back into entrepreneurship research: A meta-analysis on the relationship between business owners' 
personality traits, business creation, and success. European Journal of Work and Organizational Psychology, 16, 353-385.

Rauch, A., \& Frese, M. (2007b). Born to be an entrepreneur? Revisiting the personality approach to entrepreneurship. The Psychology of Entrepreneurship, 41-65.

Rayan, R. M. (1995). Psychological needs and the facilitation of integrative process. Journal of personality, 63,397-427.

Rouse, J. (2004). Enterprise, identity and structure: A longitudinal analysis of youth enterprise experiences. $\mathrm{PhD}$ thesis, Kingston University.

Ryan, R. M., \& Deci, E. L. (2000). Self-Determination Theory and the Facilitation of intrinsic motivation, social development and well-being. American Psychologist, $55(1), 68-78$.

Sabiu, I. T., Abdullah, A., Amin, A., \& Tahir, I.M. (2018). An empirical analysis of the need for achievement motivation in predicting entrepreneurial persistence in Bumiputra entrepreneurs in Terengganu, Malaysia. Int. J. Business and Globalization, 20(2).

Segal G., Borgia D., \& Schoenfeld, J. (2005). The motivation to become an entrepreneur, International Journal of Entrepreneurial Behavior \& Research, 11(1), 42-57

Shepherd, D., Williams, T., \& Patzelt, H. (2015). Thinking about entrepreneurial decision making: review and research agenda. Journal of Management, 41(1):1146.

Stephan, U., Hart, M., \& Drews, C. (2015). Understanding Motivations for Entrepreneurship: A Review of Recent Research Evidence, Rapid Evidence Assessment paper, Enterprise Research Centre and Aston Business School, Aston University, Birmingham, B4 7ET, UK.

Uddin, R., \& Bose, T. K. (2013). Motivation, Success Factors and Challenges of Entrepreneurs in Khulna City of Bangladesh. European Journal of Business and Management, 5(16), 148-157.

Wu, W. P., \& Leung, A. (2005). Does a micro-macro link exist between managerial value of reciprocity, social capital and firm performance? The case of SMEs in China. Asia Pacific Journal of Management, 22(4), 445-463. 